\title{
Author Correction: Clinical Benefit of Basal Insulin Analogue Treatment in Persons with Type 2 Diabetes Inadequately Controlled on Prior Insulin Therapy: A Prospective, Noninterventional, Multicenter Study
}

Jelica Bjekić-Macut · Teodora Beljić Živković (1) · Radivoj Kocić

Published online: March 22, 2018

(c) The Author(s) 2018

Author Correction to: Diabetes Ther https://doi.org/10.1007/ s13300-018-0378-4

In the original publication, values of the doses of insulin glargine, the most commonly used basal insulin analogue under the 'Discussion' section was incorrectly published.

The sentence "...was similar (3100.314 \pm $110.1298 \mathrm{U} / \mathrm{kg}$ body weight/day at baseline) to that in the Swedish study $(0.33 \pm 0.16 \mathrm{U} / \mathrm{kg}$ body weight/day)".

Should actually say "...was similar (0.31 \pm $0.12 \mathrm{U} / \mathrm{kg}$ body weight/day at baseline) to that

The original article can be found online at https://doi. org/10.1007/s13300-018-0378-4.

J. Bjekić-Macut

Belgrade School of Medicine, Bezanijska Kosa

University Medical Center, Division of

Endocrinology, Diabetes and Metabolic disorders,

University of Belgrade, Belgrade, Serbia

T. B. Živković (ه)

Belgrade School of Medicine, "Zvezdara" University

Medical Center, Division of Endocrinology,

Diabetes and Metabolic disorders, University of

Belgrade, Belgrade, Serbia

e-mail: dorabeljic@beotel.net

R. Kocić

Clinic for Endocrinology, Faculty of Medicine,

University of Nis, Nis, Serbia in the Swedish study $(0.33 \pm 0.16 \mathrm{U} / \mathrm{kg}$ body weight/day)".

Open Access. This article is distributed under the terms of the Creative Commons Attribution-NonCommercial 4.0 International License (http://creativecommons.org/licenses/ by-nc/4.0/), which permits any noncommercial use, distribution, and reproduction in any medium, provided you give appropriate credit to the original author(s) and the source, provide a link to the Creative Commons license, and indicate if changes were made. 